\title{
Artful Innovation
}

\section{Learning from Experiments with Audiences in Symphonic Music Practice}

Peter Peters, Ties van de Werff, Ruth Benschop \& Imogen Eve

In the $21^{\text {st }}$ century, symphonic music institutions face major challenges that question their traditional ways of operating. Whereas symphonic music was a vital element in the European cultural landscape until the 1960s, it has since become a museum art form, as has been argued, for example, by Peter J. Burkholder (2006), and its relevance has been questioned (see, for instance, Johnson 2002). The social value of classical orchestral music has changed profoundly, and its identification with high culture is no longer uncontested. In the Netherlands, as in many other affluent Western countries, these developments are accompanied by stagnating audience numbers (e.g. Raad voor Cultuur 2014), and a decrease in government funding. Extramusical success criteria are formulated that should ensure that government investment benefits not only the established audiences. However, a neoliberal focus on quantifiable results, fuelled by policies to increase market-generated income, has not fundamentally changed symphonic music practice. The majority of symphony orchestras continue to organise concerts in concert halls for an audience that knows what to expect (Johnson 1994). The roles of the various actors in this practice - musicians, managers, music educators, audience members - are codified in a standard model of the production and consumption of canonical compositions. Most classical music concerts have the character of a ritual that is loved and valued by musicians and audiences alike.

In recent years, however, many orchestras in European countries have taken up the challenge to innovate. They have introduced new formats to engage with existing audiences and attract new audiences, such as people of differing social and cultural backgrounds (Idema 2012, Topgaard 2014, Hamel 2016). In addition to strategies to innovate concert formats, orchestras are 
presenting their performances online through live or recorded streaming services. European Union research programs such as Creative Europe have funded international research projects on innovation within the classical music experience. Most orchestras are now involved in a variety of practices which we can call Musikvermittlung, in the form of education, new concert designs and community music projects (Wimmer 2010, Hill/de Banffy-Hall 2017, Higgins/Willingham 2017, Uhde 2018).

In this chapter we will present two experiments involving innovation with a symphony orchestra, with the aim of showing what innovation and participation entail in practice. We draw on the four-year "Artful Participation" project, funded by the Dutch research foundations NWO and SIA. ${ }^{1}$ The "Artful Participation" project seeks to innovate within the practice of symphonic classical music by asking what it means to participate in it as an audience. How can artistically meaningful innovations be introduced into traditional forms of audience participation that are dominant in the current symphonic practice? Instead of asking how the standard model can be adjusted, we aim to more fundamentally rethink the roles and competences that the various actors bring to and develop in this practice. To do so, the project orchestrated an exchange between the symphonic music practice and social-science research on participation, experimentation and innovation, drawing on concepts and methods from audience research (e.g. Pitts et.al. 2013), science and technology studies (STS) (e.g. Bijsterveld/Schulp 2004, Lezaun et al. 2016) and artistic research (Biggs/Karlsson 2010, Borgdorff 2012). As an interdisciplinary and collaborative project, researchers, orchestra musicians and staff, as well as conservatory students and audiences, worked together on it.

The project consisted of three experiments in audience participation. In the current symphonic practice, audiences are mostly involved as passive listeners, consumers or amateurs when it comes to the expertise of assessing

The "Artful Participation" project, funded by the Dutch Research Council (NWO) and the Dutch Taskforce for Applied Research (SIA) under the project number 314-99-204, is a collaboration between Maastricht University (UM), philharmonie zuidnederland (South Netherlands Philharmonic) and Zuyd University for Applied Sciences (Zuyd), which houses the Conservatory. These organisations started a structural collaboration at the Maastricht Centre for the Innovation of Classical Music (MCICM) in 2018. From 2018 to 2021, the researchers of the "Artful Participation" project (Peter Peters, Ruth Benschop, Ties van de Werff, Imogen Eve and Veerle Spronck), together with the musicians and staff of the orchestra, designed, organised and gave three experimental concerts. 
the quality of the performance. In the "Artful Participation" project, we experimented with the contrasting roles of maker, citizen and expert by actively involving audiences in co-creating, programming and assessing symphonic music. The reflection on these experiments resulted in a learning model that will help to bring innovation to classical music practice. This learning model acknowledges that innovations in practice require specific kinds of efforts by all involved. It is through making this practical work explicit that all participants are able to learn. After having outlined our theoretical and methodological approach to the experimental research in symphonic practices, we will elaborate on two experiments and draw conclusions on learning through experimenting in orchestral practice.

\section{Theoretical Approach: Learning in a Symphonic Practice}

Drawing on studies and concepts from science and technology studies, we understand classical symphonic music as a material social practice. Our analytical focus is on all the activities that are necessary to produce, perform and distribute music, as well as on the materiality of musical performance and experience. Analogously, we radically conceptualise a musical work as an entity that has to be continually performed and worked upon to exist at all. In doing so, we intend to move beyond the traditional distinction between research on the artwork itself and the practices and contexts in which it is produced and consumed. Instead, taking an STS perspective on orchestral music, we focus on the performative ontology of artworks, such as musical compositions (Pickering 1995).

\section{Musical performance as a socio-material practice}

Following the sociologist of art Howard Becker, we open a network-perspective on art: in order to exist, art has to be performed by multiple actors in changing relational networks that constitute art worlds. These consist of "all the people whose activities are necessary to the production of the characteristic works which that world, and perhaps others as well, define as art" (Becker 1982: 34). Analogously, we understand classical symphonic music as a socio-material practice. This theoretical assumption shifts the analytical focus to the actual work necessary to produce, perform and distribute music, as well as to the materiality of musical performance and experience. This res- 
onates with the work of Christopher Small, who has turned the noun "music" into the verb "musicking": "[T]o take part, in any capacity, in a musical performance, whether by performing, by listening, by rehearsing, or practicing, by providing material for performance (what is called composition), or by dancing" (Small 1998: 9-10). It also draws on the work by Finnegan (2007) on amateur musical practices and by Hennion (e.g. 2001), who ethnographically studies how amateurs of music form attachments to music in concrete practices (Oudshoorn/Pinch 2003, see also Born/Barry 2018). These vocabularies enable us to analyse what it means to take part in a musical performance and to question and move beyond codified repertoires of action in symphonic music practice (Acord/DeNora 2008).

Our focus on musical performance as a socio-material practice opens up the space for experimenting with new norms and forms of artistically meaningful audience participation. We deliberately do not pre-define what artistically meaningful audience participation is. Instead, this is a topic of empirical experimentation. Our notion of experiment draws on a concept of innovation that does not refer to clever inventiveness or an ideology of technological newness. Rather, we see innovation as resulting from the capability to learn (see Benschop/Peters 2009, Godin/Vinck 2017, Hommels et al. 2007). To innovate a practice through participatory experiments, then, means to cultivate, strengthen and deepen the capability for (mutual) learning: what can musicians, staff, and researchers collaboratively learn about their own practice when involving audiences in the organisation, performance, and assessment of symphony music?

\section{Three forms of learning in practice}

We learn by doing, in practice. Using recent studies of innovation in science and technology in practice, and building on traditions within educational theory and action research that emphasise the embodied, enacted and situational dimensions of learning over purely cognitive, applied or linear approaches (see Dewey 1933, Freire 1972, Kolb 1984, Lewin 1946), we distinguish between three forms of learning. Therapeutic learning takes place when practitioners, probed by an external observer, become aware of the routines, skills and knowledges that normally remain implicit and tacit in their daily activities (e.g. regarding imagined audiences or implicit notions of quality or success). This form of learning can be called therapeutic because of the traditional questioning and facilitating role of the researcher as a critical friend, 
slowing the practice down in order to reflect on it (see Hommels et al. 2007, Benschop/Peters 2009). Experimental learning denotes a collaborative learning by developing and practicing new knowledges, skills and ways of working through experiments that challenge established routines, roles and ways of working. Doing things differently deliberately generates a heightened reflexivity in which normativities, attachments, risks and stakes are made explicit (see Lury/Wakeford 2012, Marres et al. 2018, Zuiderent-Jerak 2015). This can be difficult for a symphony orchestra, where routines and ways of working have a long and highly valued tradition. Finally, reflexive learning takes place when reflection has become an integral part of the practice or organisation of the practitioner, which allows for improved ability to cope with uncertainties and anticipate unexpected changes (see Schön 1984, Iedema et al. 2013). Eventually, we aim to instil a willingness, openness and desire among staff and musicians of the orchestra to do things differently in order to learn.

\section{Methodological Implications: Artistic Research and Ethnography}

Our theoretical approach towards learning through experimentation with a symphony orchestra has methodological implications for the role that we as researchers can and should take. We draw on expertise in the field of artistic research and methods of ethnography. The aim of artistic research is not to explain the artistic practice, to objectify it, or to legitimise it. Artistic research presupposes that artists contribute to research through artistic practice (see Biggs/Karlsson 2010, Borgdorff 2012). Artistic research is not a goal in itself, it is a means to question and to focus artistic practice (Benschop 2020). In the context of this project, this means that research into the innovation of participation in symphonic music practices will have the explicit goal of learning through collaboratively organising, performing, and assessing symphonic music concerts. In the "Artful Participation" project, a musician-researcher trained as a classical violinist - worked closely with researchers, musicians and staff from the orchestra to design the experiments as artistically meaningful events.

\section{Observing and intervening}

Methodologically, our experiments combine ethnographical observations and active interventions by the researchers, drawing on interventionist and action 
research practices (Bradbury 2015, Lezaun et al. 2016, Lury/Wakeford 2012). Ethnographic methods, and qualitative research methods in general, are especially suitable for learning in practice, as they give researchers the systematic means to hone, calibrate, position and thus critically question and develop themselves as instruments. We draw inspiration from Tim Ingold's notion of "the art of inquiry" (Ingold 2013), where he argues that the fundamental task of anthropologists is not to gather data and build knowledge, but to learn from the practices in which they immerse themselves, in order to speculate about future possibilities. Developing, performing and evaluating the experimental concerts were collaborative endeavours in which we as researchers closely worked with orchestra staff and musicians with the goal of tracing and documenting the learning that took place throughout the process. All the researchers involved (the musician-researcher and the academic researchers) took on the role of participant-observers during the organisation and performance of the experimental concerts.

In the following three sections, we present two experiments in artful participation. What these experiments share is that they took works from the canon of Western art music as a starting point. Instead of tinkering with elements of the codified performance history of these works, the musician-researcher in our project designed concert events that required all participants to adapt their expectations of what a musical performance actually entails: musicians were asked to arrange music for a specific spatial setting, such as a local pub; and audience members were invited to take a more active role in organising the concert. These experiments were designed so that new and unexpected values and qualities could emerge from the situation. Our leading question in these experiments was: how to design and experiment with artistically relevant forms of audience participation in the symphonic music practice, and learn from these experiments?

\section{"Mahler am Tisch": An Imagined Audience}

It is seven in the evening, a mid-November night in 2019 at Café Tribunal in the city centre of Maastricht, the Netherlands. The place is very crowded, as always on a normal day like this. People are chatting at the bar and sitting at tables to eat something. As in many old-fashioned Dutch cafés, the floor is covered with peanut shells: the owner offers free nuts with the drinks. There are early Christmas decorations on the walls. At one end of the café, people 
are sitting around a group of five string players and a harpist. One of the violinists stands up and raises her voice to speak. She says that the musicians will perform a piece by Gustav Mahler, the slow "Adagietto" from his "Fifth Symphony". She explains that this music is very soft and invites everyone to be silent for a moment. After some hushing, people stop talking or lower their voice. When the musicians start to play their first notes, they realise that their improvised audience is becoming silent and starting to listen. Emerging from the muffled buzz at the bar, Mahler's notes seem to create a shared feeling of attention to something that is not often heard in this café.

Playing the "Adagietto" had been the particular wish of the string players when they were asked to participate in the experiment "Mahler am Tisch". It was designed to enable people to experience Mahler's music through the folk music and the village songs and dances that inspired him. Three bands were formed by musicians from the philharmonie zuidnederland and local semiprofessional and amateur players. The ensembles corresponded to different aspects of Mahler's music: a klezmer band, a brass band, and a string quartet. Collaborating with the musician-researcher in the project, each group chose the music that they would like to perform. The musicians actively participated in the process of arranging parts of the original orchestral score and of finding other folk music that resonated with Mahler's musical world. They created a set list that was entirely their own. The ensembles then performed on four subsequent nights at two local cafés in Maastricht, where they played "am Tisch" - around the table. One is a small music café, which regularly features jazz performances. The second is a typical local bar, where (art) students and other residents of Maastricht come for a drink after studies or work.

\section{Arranging and rehearsing with uncertainties}

The rehearsals of the musicians were an important part of the experiment. During the arrangement and practicing process, we encouraged the musicians to imagine and musically acknowledge their audiences during the concerts in the cafés (Litt 2012). Most musicians were familiar with the two bars. At the first rehearsal, the repertoire proposal made by the musicianresearcher was discussed. One musician of the brass ensemble argued that he preferred to play folk music instead of excerpts from Mahler, because "Mahler's music won't work in a bar, the audience will find it boring, hearing just brass players" (Observations from brass rehearsal, written up by Ties van de Werff, November 18, 2019). Eventually, the ensembles did arrange 
excerpts from Mahler's music for their specific bands. The brass quintet, for example, used excerpts from Mahler as well as traditional Austrian folk songs. For one piece, they combined parts of Mahler's "Urlicht" from the "Second Symphony" and some traditional Austrian dances. The musicians negotiated between the artistic freedom of arranging Mahler for bar performance, their own habits and routines of playing, and the ideals of fidelity to the score and faithfulness to the composer's intent. After the brass quintet rehearsed "Urlicht" from beginning to end, one of the musicians remarked: "I don't know, I don't feel the interaction with the original composition anymore" (Observations from brass rehearsal, written up by Ties van de Werff, November 18 2019). The other musicians were more enthusiastic, as the trumpet player responded: "This sounds exactly like the kind of folk music that Mahler could have used" (Observations from brass rehearsal, written up by Ties van de Werff, November 18, 2019). During the rehearsals of all three ensembles, the musicians were quite reflective about the way they were supposed to play. They imagined the setting and acoustics of the bar, the people that would be present, and how the music should sound. The musicians often created a contrast between a way of playing that is common in the concert hall and a performance style that would suit a busy café on a Saturday evening. The musicians alternated between the perceived "loose" character of their own arrangements, and the more "substantial" excerpts of Mahler's compositions. For example, when talking about one particular Mahler excerpt, the trumpet player explained to his fellow brass musicians that "[i]t should sound refined, not sloppy [...] If people recognise it as Mahler, then we shouldn't play it too loosely" (Observations from brass rehearsal, written up by Ties van de Werff, November 18, 2019). When comparing the different arrangements, a musician remarked: "We have to play chic after those eight bars of vulgarity." Musicians used adjectives such as "refined", "articulated" and "precise" to refer to a more familiar way of playing Mahler. In contrast, other pieces were perceived as allowing for a different style of playing. When discussing the tempo of an arrangement and the perceived acoustics of the two bars, a musician remarked: "It should gather some pace, we are not an orchestra. If there is one moment that we can overplay it, it is here. Not too calculated, not too classical." Or: "It shouldn't sound too etude-like, we can make it a bit lighter" (Observations from brass rehearsal, written up by Ties van de Werff, November 18 2019). Discursive qualifications such as these functioned as a way for musicians to uphold their routine ways of rehearsing in an uncertain situation. 
Realising the concerts according to the design was by no means a frictionless affair. In order to create a sociable atmosphere in the café, the (musician-)researcher involved encouraged the musicians to play the arrangements, where possible, by heart. Playing without scores would not only fit the folk-style of playing that we envisioned, but would also get rid of the music stands that could have the effect of being a visual barrier between the musicians and the people in the café. While some musicians in the klezmer band did play by heart, the orchestra musicians refused to do that. They argued that it was impossible to learn the score in the time that they were given for rehearsing, or that they would feel uncomfortable to do so. We also encouraged the musicians of the ensembles to pay attention to the visual presentation of their playing. In the string ensemble, for example, the musicianresearcher asked the musicians to play outwards more: to show the pleasure and fun of playing together, as a team or a band, instead of focusing on the precise articulation of the music. She also encouraged the musicians to play in a more communicative style, for example by looking at each other, or using bow gestures to emphasise different parts of the music. Some musicians felt reluctant to follow these suggestions, others were more at ease with them. As a trumpet player told the tuba player: "You have to act a bit comical, don't put on such an artistic face" (Observations from brass rehearsal, written up by Ties van de Werff, November 18, 2019). Eventually, the musicians were taking more ownership of the concerts, making their own decisions instead of following the original ideas. During the concerts, some musicians did in fact respond to the encouragements of the musician-researcher to perform in a communicative style, with each other and with the audience.

\section{An experiment in opening up routines}

The "Mahler am Tisch" experiment was designed to create a situation in which going back to Mahler's folk music roots would allow for a convivial interaction between musicians and people in the café. Making music together, talking, laughing and enjoying the fun of playing together was the aim, not so much a performance that was perfect according to traditional classical music values. Trying to implement this vision, and imagining the audience, taught us and the musicians a lot about the implicit routines in the musicians' rehearsal and performance practices. The contrast that musicians made between (imagined) concert hall audiences and café audiences made them and us aware of different ways of playing, and the possible pre-conceptions about (imagined) 
audiences that these musical choices presuppose: even though the bar was not a concert hall, audiences present could have been (and some were) frequent classical concert visitors. This therapeutic learning by making the implicit explicit also made visible what such an experiment asked of everyone involved: the musicians, the researchers and the people present in the two cafés. Without conventional props, such as a concert costume and a stage, a clear distribution of artistic responsibilities, shared criteria for a good performance, and an attentive and silent audience, the musicians felt vulnerable. As intervening researchers, we had to find a balance between the initial artistic ideals of the experiment and the realities of tight concert schedules, planning and communication issues, shifting and contested artistic authority, and last-minute logistical improvisations to get everything and everyone in place at the right time. For the people in the café who responded to the invitation to become an audience - many of whom suddenly found themselves in a musical situation, as the event was only minimally advertised beforehand-it meant that they had to give up their conversations with others and offer their ears and attention to music that they had not asked for. Making the experimental concerts happen therefore required work that led to collaborative learning about what makes a musical performance both vulnerable and valuable.

\section{The People's Salon: A Co-Responsible Audience}

In the second experiment, entitled "The People's Salon", the Friends of philharmonie zuidnederland were invited to program a symphonic concert evening. Through qualitative interviews and two focus groups with fifteen Friends, personal stories and memories were collected about how a particular classical music composition had been important for them during certain moments or phases in their lives. In the focus groups, the Friends were very open and sometimes emotional when sharing their personal memories and stories. Some were mundane, as in the case of a Friend who liked to listen to symphonic music in her car because it made the noise of the engine less annoying. Others were more emotional, such as one Friend who listened to Rachmaninoff's "Second Piano Concerto" in the week his wife passed away, and now feels that she figuratively winks at him when he accidentally hears this music. The focus group meetings and the semi-open interviews with individual Friends made it clear that hearing other people's memories and stories about music provided a starting point for intense conversations about the meaning 
and importance of classical music in people's lives. This element of conversation led the musician-researcher to envision the concert as an intimate musical evening, such as had originated in bourgeois Paris salons around 1900. In these salons, musical performances facilitated and triggered a meeting of minds. Through their exchange of stories and memories about the meaning of classical music in one's life, the Friends thus took co-responsibility for the program, as well as for the character of the event.

\section{Sharing artistic responsibilities}

The main challenge in this experiment was to share and distribute the artistic tasks and responsibilities for organising the concert evening between the Friends involved, the researchers, and the orchestra staff, specifically the artistic programmer. Based on the interviews and the first focus group, the researchers proposed a storyline of recurring themes: childhood memories, love stories, everyday life situations (such as listening to the car radio), and consolation at moments of loss and sorrow. This provided a potential structure for the concert program. The group of Friends felt very responsible for the process, as one of them noted in an evaluative survey afterwards: "Especially after the first meeting, I really felt like a co-programmer, for a beautiful musical evening" (Van de Werff 2020). Responsibility in an artistic sense was also felt when making final decisions on the program for the evening. This was challenging for some Friends, as it meant that "you cannot take into account all of the beautiful, personal and dear memories, which means that we will have to disappoint some people" (Van de Werff 2020). Others found it challenging to accept "different views on musical tastes", or to come up with "workable ideas" (Van de Werff 2020).

During the second focus group, it turned out that the Friends had selected mainly solo and chamber music works, whereas a medium size symphony orchestra had been scheduled. Since there were not enough personal stories related to orchestral works, the artistic programmer of the orchestra and the researchers had to artistically intervene by suggesting some symphonic pieces. By doing so, we could also take the Friends along in the decision-making process that usually belongs to the artistic programmer: taking into account the instrumentation of the scores and the number of available musicians, the costs of hiring extra musicians or adapting an arrangement to fit the instrumentation. Eventually, the Friends, the researchers and the artistic programmer agreed on two symphonic compositions that were fea- 
sible in terms of the available musicians and rehearsing time, and also fitted the themes of the evening.

For practical and logistical reasons, such as a lack of time, finding a suitable venue for the concert evening was done by the researchers. We first enquired about two historical locations in the city centre of Maastricht which have the late nineteenth-century atmosphere that invokes the atmosphere of Proustian music salons, but they were not available in January 2020 . That made us reflect on this decision: we were not aiming to re-enact the $19^{\text {th }}$ century salon and its social context. Rather, we wanted to use the salon as a guiding metaphor, for bringing conversation and music together, around meanings of classical music in our lives. We then found an old cement factory just outside the city centre, called AINSI. It has been refurbished as a cultural venue, and offers a large foyer with many sofa seats placed among the remaining industrial equipment. Aesthetically, it provided a contemporary rawness of concrete walls and ceilings, combined with old carpets, tables and armchairs (see Figure 1). It also has a relatively standard black box theatre hall that accommodates an audience of 150 . This limited the maximum number of Friends that could attend. Once all the 2,500 Friends of the orchestra had been informed about the concert, which was offered to them for free, it only took one day to reach the maximum number of reservations.

The idea was to use the different spaces in the AINSI venue to create not only a musical stage, but also an environment where audiences could converse. In the focus groups, we also discussed the stage design and the way we could include some stories in the set-up of the concert evening. The musician-researcher had proposed to stage the stories in various places and invite the audience members to walk from one to the other, as a metaphorical journey through life. This would require careful management of the movements of both the musicians and the audience during the concert, so shortly before the concert the researchers decided to perform all music in the hall and have the conversations in the foyer. The Friends and researchers together then decided to ask some Friends to present their stories live during the concert, in a talk-show manner with a host. This role was taken by the timpanist of the orchestra. We also asked the Friends, as ambassadors of classical music, to start conversations with audience members in the break and after the concert about the value of classical music in one's life. The Friends were motivated to take up this role, as some liked the idea of making classical music "more accessible", "closer to the people" and to reach "normal audiences, and not only the diehard experts" (Van de Werff 2020). 


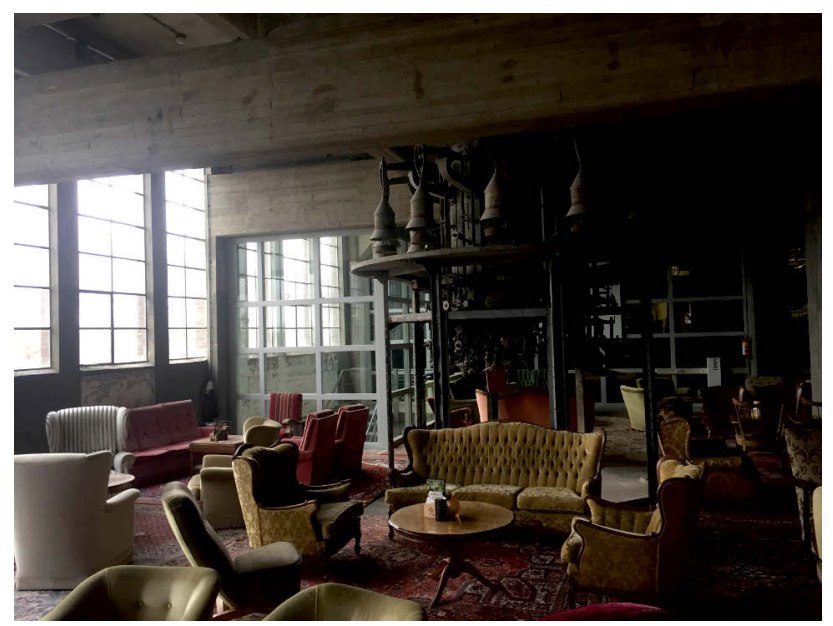

Source: Peter Peters

\section{Staging a salon}

The actual staging of the event in the days before the concert was done by the musician-researcher together with technical staff from the orchestra and AINSI. She had to constantly negotiate between her original design ideas and a host of smaller and bigger resistances: the position of the smaller ensembles that would perform chamber music, as well as the position of the orchestra; the size of the hall itself, as well as its acoustic limits with regard to where the musicians and the audience could be situated. Using coloured lights to change the atmosphere between pieces led some of the musicians to protest because they could not read their scores. In a last-minute attempt to prevent the staging from falling back into a conventional orchestral performance setting, she brought some of the sofas from the foyer and added small tables with flowers, which was met with some hesitance from the orchestra production crew. Eventually, the evening went smoothly: the alteration between the presented stories of the Friends on stage and performances of works such as Wolfgang Amadeus Mozart's "Rondo alla Turca", Nikolai Rimski-Korsakov's "Sheherazade" or Johann Sebastian Bach's “Third Brandenburg Concerto" gave 
the attending audience a sense of familiarity, as could be heard from their responses during the evening.

What actually happened on January $25^{\text {th }}, 2020$, in AINSI, was different from the initial design presented by the musician-researcher. Moving from the story board to the actual concert brought together a large group of people: Friends, orchestra musicians and staff, technical staff of the orchestra and the venue, and us as researchers. By deliberately changing important aspects of the programming and designing of the orchestral event, we learnt that seemingly trivial choices regarding the stage design or walk-through of the audience turned out to be artistically important for creating the right atmosphere, fitting the artistic programming of the evening. Materials - ranging from the concrete structures of the building and its acoustics, derelict industrial equipment and old sofas, to the program notes that offered the stories to the audience - all contributed to the artistic quality of the musical situation on the night of the concert. This insight in itself is obviously not new for all involved; the production leader of the orchestra was well aware of the artistic consequences of his choices. The experiment, however, made this visible and negotiable for researchers, audiences, musicians and staff alike.

While we aimed at sharing artistic responsibility with the Friends as codesigners, in the end we learnt that artistic responsibilities circulated among the people and materialities at the concert. Listening to personal stories not only contributed to a different listening experience, as some of the Friends voiced in a focus group after the concert, but also opened up ways to make classical music matter to people in a different way. For their part, the orchestra musicians said that they felt the dedication of the audience in the intensity of their attention. The artistic programmer and other orchestra staff members involved reflected on the possibility that this experiment could become a concert format that can open up the ways audiences are able to relate to classical music.

\section{Conclusion: Learning through Experimenting}

What lessons can we draw from these experiments? What does it mean for an orchestra to be a lab and collaborate with academic and artistic researchers? What do we as researchers learn from our work with orchestra musicians and staff? 


\section{Learning to do things differently}

One important lesson we learned together is that in regular symphonic practices, audiences are always imagined throughout the entire process of programming, organising, producing, performing and assessing classical music concerts. To make all the musicians and staff involved aware of this, and make their imagined audiences explicit, is a first step when the aim is to rethink the artistic role that audiences can have in innovative concert formats. The artistic design of the concert events implied that the musicians rehearsed with the explicit question of how the audience would contribute to their performance, as we have seen in the experiment "Mahler am Tisch". This opened up musical and non-musical choices for the musicians, such as using music stands or not, or making on-the-spot changes to the music during rehearsals to make it fit the situation, and made them more aware of their style of playing and their stage presence. When such imaginings become part of the rehearsal practice, they can be questioned, challenged and imagined differently - only when such routines become visible through therapeutic learning, can there be experimental learning: learning to do things differently. Instead of "outsourcing" artistic responsibility to the audience members as unpaid amateurs, in "The People's Salon" they were invited to take co-responsibility as citizens for the practice they care about deeply by making visible how classical music can matter to different people in different ways. Sharing their stories showed how audience members literally live with classical music instead of just consuming it at concerts, as a neoliberal view would have it. Moreover, by experimenting with a different stage set-up and stage design, it became visible how artistic choices circulate between people and materials, helping to enable the musical situation to unfold. This awareness allows production crew, musicians and the staff of the orchestra to imagine possible different concert situations.

\section{Reflexive learning: a challenge for a routinised practice}

As in our experiments, any orchestral concert requires that everything comes together at exactly the right moment. Planning for this right moment in a large organisation is incredibly complex and requires routines and experience. We have learned that this production logic often interferes with the creation logic that is assumed in artistically meaningful experiments. In the organisation and production of classical music concerts, especially innovative concert formats, seemingly small things can come to matter artistically: 
from the position of musical stands on stage and the way an ensemble is arranged, to the body language of musicians and the staging of the audience and its expectations. To acknowledge the interactions and tensions between the two logics requires stepping away from a hierarchical and compartmentalised view of artistic choices and artistic responsibility - which can be challenging and difficult in the daily practice of symphony orchestras.

In order for experiments to have an innovative and sustainable impact on the design and organisation of classical music concerts, it is evident that various forms of learning are needed. It takes time and effort to learn: to become explicitly aware of implicit routines (therapeutic learning), or to learn from trying to do it differently (experimental learning). Through the combination of observation and intervention, academic and artistic research, we aimed to cultivate forms of learning that differ in their degree of reflexivity and awareness, imagining alternative routines. In our experiments, we aimed to challenge ingrained notions of audiences or the musical work, in order for musicians and staff to become aware of the potential to change them. What our experiments suggest is that artistically meaningful innovation requires reflexive learning over time. Experiments such as "Mahler am Tisch" and "The People's Salon" - which both combined therapeutic learning with experimental learning - can be seen as stepping stones for reflexive learning: the ability of musicians and staff to cope with uncertain musical situations, and unexpected changes to their routines. Such reflexive learning has to be integrated into the everyday practices of both staff and musicians in order to benefit the workings of the entire orchestra. This implies making strategic choices, such as allocating time and money in ways that might challenge the core business of the orchestra. As there is a lot at stake when innovating an institution like a philharmonic orchestra, this requires a committed combination of care and courage from all involved. 


\section{Bibliography}

Acord, Sophia Krzys/DeNora, Tia (2008): Culture and the arts: From art worlds to arts-in-action, in: The Annals of the American Academy of Political and Social Science, Vol. 619, No. 1, 223-237.

Becker, Howard. S. (1982): Art Worlds, Berkeley: University of California Press.

Benschop, Ruth/Peters, Peter (2009): Samen Innoveren. naar een Europees niveau in de podiumkunsten, Maastricht: Zuyd Hogeschool.

Benschop, Ruth (2020): A Thought Experiment on Artistic Research as HighRisk Ethnography, in: Borgdorff, Henk/Peters, Peter/Pinch, Trevor (eds.), Dialogues Between Artistic Research and Science and Technology Studies, London: Routledge, 46-60.

Biggs, Michael/Karlsson, Henrik (eds.) (2010): The Routledge Companion to Research in the Arts, London: Routledge.

Borgdorff, Henk (2012): The Conflict of the Faculties. Perspectives on Artistic Research and Academia, Leiden: Leiden University Press.

Born, Georgina/Barry, Andrew (2018): Music, Mediation Theories and ActorNetwork Theory, in: Contemporary Music Review, Vol. 35, No. 5-6, 443-487.

Bradbury, Hilary (ed.) (2015): The Sage Handbook of Action Research, [3 ${ }^{\text {rd }}$ edition], Thousand Oaks, CA: Sage.

Burkholder, J. Peter (2006): The Twentieth Century and the Orchestra as Museum, in: Peyser, Joan (ed.), The Orchestra: A Collection of 23 Essays on its Origins and Transformations, Milwaukee, WI: Hal Leonard Corporation, 408-433.

Bijsterveld, Karin/Schulp, Marten (2004): Breaking into a World of Perfection. Innovation in Today's Classical Musical Instruments, in: Social Studies of Science, Vol. 34, No. 5, 649-674.

Dewey, John (1998) [1933]): How we Think: A Restatement of the Relation of Reflective Thinking to the Educative Process, Boston: Houghton Mifflin.

Finnegan, Ruth (2007): The Hidden Musicians: Music-Making in an English town, Middeltown, CT: Wesleyan University Press.

Freire, Paulo (1972): Pedagogy of the Oppressed, New York: Herder and Herder.

Godin, Benoit/Vinck, Dominique (eds.) (2017): Critical Studies of Innovation: Alternative Approaches to the Pro-Innovation Bias, Cheltenham (UK): Edward Elgar Publishing.

Hennion, Antoine (2001): Music Lovers. Taste as Performance, in: Theory, Culture \& Society, Vol. 18, No. 5, 1-22. 
Hamel, Micha (2016): Speelruimte voor klassieke muziek in de 21ste eeuw, Rotterdam: Codarts.

Higgins, Lee/Willingham, Lee (2017): Engaging in Community Music. An Introduction, New York/London: Routledge.

Hill, Burkhard/de Banfy-Hall, Alicia (eds.) (2017): Community Music. Beiträge zur Theorie und Praxis aus internationaler und deutscher Perspektive, Münster/New York: Waxmann.

Hommels, Anique/Peters, Peters/Bijker, Wiebe E. (2007): Techno therapy or nurtured niches? Technology studies and the evaluation of radical innovations, in: Research policy, 36(7), 1088-1099.

Idema, Johan (2012): Present! Rethinking Live Classical Music, Amsterdam: Music Center the Netherlands.

Iedema, Rick/Mesman, Jessica/Carroll, Katherine (2013): Visualising Health Care Practice Improvement: Innovation from Within, London: Radcliffe Publishing.

Johnson, James H. (1994): Listening in Paris: A Cultural History, Berkeley/Los Angeles/London: University of California Press.

Johnson, Julian (2002): Who Needs Classical Music? Cultural Choice and Musical Value, Oxford: Oxford University Press.

Kolb, David A. (1984): Experiential Learning: Experience as the Source of Learning and Development (Vol. 1), Englewood Cliffs, NJ: Prentice-Hall.

Lewin, Kurt (1946): Action Research and Minority Problems, in: Journal of Social Issues, 2(4), 34-46.

Lezaun, Javier/Marres, Noortje/Tironi, Manuel (2016): Experiments in Participation, in: Felt, Ulrike/Fouché, Rayvon/Miller, Clark A./Smith-Doerr, Laures (eds.), The Handbook of Science and Technology Studies, [4 ${ }^{\text {th }}$ edition], Cambridge, Massachusetts/London, England: The MIT Press, 195-221.

Litt, Eden (2012): Knock, Knock. Who's there? The Imagined Audience, in: Journal of Broadcasting \& Electronic Media, Vol. 56, No. 3, 330-345.

Litt, Eden/Hargittai, Eszter (2016): The Imagined Audience on Social Network Sites, in: Social Media + Society, Vol. 2, No. 1, 1-12.

Lury, Celia/Wakeford, Nina (eds.) (2012): Inventive Methods: The Happening of the Social, London: Routledge.

Marres, Noortje/Guggenheim, Michael/Wilkie, Alex (2018): Inventing the Social, Manchester: Mattering Press.

Oudshoorn, Nelly/Pinch, Trevor (eds.) (2003): How Users Matter. The CoConstruction of Users and Technology, Cambridge, MA: MIT Press. 
Pickering, Andrew (1995): The Mangle of Practice: Time, Agency, and Science, Chicago: University of Chicago Press.

Pitts, Stephanie E./Dobson, Melissa C./Gee, Kate/Spencer, Christopher P. (2013): Views of an audience: understanding the orchestral concert experience from player and listener perspectives, in: Participations: Journal of Audience and Reception Studies, Vol. 10, No. 2, 65-95.

Raad voor Cultuur (2014): De Cultuurverkenning. Ontwikkelingen en trends in het culturele leven in Nederland, Den Haag: Raad voor Cultuur.

Schön, Donald A. (1984): The Reflective Practitioner: How Professionals Think in Action (Vol. 5126), New York: Basic books.

Schulze, Gerhard (2005): Die Erlebnisgesellschaft: Kultursoziologie der Gegenwart, Frankfurt: Campus Verlag.

Small, Christopher (1998): Musicking: The Meanings of Performing and Listening, Middletown, CT: Wesleyan University Press.

Topgaard, Richard (2014): How the Lion Learned to Moonwalk and Other Stories on How to Design for Classical Music Experiences, Malmö: Malmö University.

Uhde, Folkert (2018): Konzertdesign: Form follows Function, in: Tröndle, Martin (ed.): Das Konzert ${ }^{I I}$ : Beiträge zum Forschungsfeld der Concert Studies, Bielefeld: transcript, 121-149.

Van de Werff, Ties (2020): Survey: Ervaringen bij het organiseren van de Vriendensalon, retrieved May 19.

Wimmer, Constanze (2010): Exchange. Die Kunst, Musik zu vermitteln. Qualitäten in der Musikvermittlung und Konzertpädagogik, Salzburg: Stiftung Mozarteum Salzburg.

Zuiderent-Jerak, Teun (2015): Situated intervention: Sociological Experiments in Health Care, Cambridge \& London: MIT Press.

\section{Biographical notes}

Peter Peters is professor at the Faculty of Arts and Social Sciences of Maastricht University and director of the Maastricht Centre for the Innovation of Classical Music (MCICM). The MCICM is a collaboration between philharmonie zuidnederland, Zuyd University of Applied Sciences and Maastricht University. Peter has a background in sociology and philosophy. His current research combines a lifelong passion for music with an interest in how artistic practices can be a context for doing academic and practice-oriented re- 
search. He focuses on innovating classical music practices, specifically symphonic music.

Ties van de Werff is a researcher at the Research Centre for Arts, Autonomy and the Public Sphere of Zuyd University of Applied Sciences, and was a postdoc at the MCICM. Ties has a background in science and technology studies, empirical philosophy, and social design. His research interests lie in the ethics of societal engagement practices, both in the sciences and in the arts. Specifically, Ties explores how artists, scientists, and societal intermediaries engage with different valuations of the good, when making their work valuable for others.

Ruth Benschop is reader at the Research Centre Autonomy and the Public Sphere in the Arts at of Zuyd University of Applied Sciences, Maastricht. Ruth was trained as a theoretical psychologist at Leiden University and finished her $\mathrm{PhD}$ (with honours) at the University of Groningen in 2001. Two old fascinations brought her to her current workplace at the Faculty of the Arts. Her interest in the rich interspace between academic and artistic practices on the one hand. On the other, her affinity with the innovative methodological and exploratory opportunities of qualitative, participatory research.

From an early career in classical music and theatre, Imogen Eve now works as an artistic researcher, writer and ethnographer in the performing arts. As a director-designer, Imogen blends her formative training as a musician and an actor to create immersive and interactive storytelling experiences through live music performance. In the Artful Participation project, Imogen developed research experiments in the form of music performance platforms. These aimed to innovate symphonic music through audience participation, and shaped the research trajectory of the project through artistic practice. 